\title{
AS PENAS PREVISTAS NO CÓDIGO PENAL BRASILEIRO E A REINCIDÊNCIA CRIMINAL
}

\author{
Heloíza dos Santos Lima ${ }^{1}$
}

RESUMO: Este estudo abordará as possibilidades de penas previstas no ordenamento jurídico brasileiro e as causas da reincidência criminal, e, a precariedade do sistema carcerário brasileiro. O objetivo central do referido trabalho é fazer uma análise minuciosa de como as políticas públicas são falhas, e com isso, contribui para o aumento da reincidência. Como forma de alcançar o objetivo, foi utilizado a metodologia dialética, na qual fará um paralelo comparativo entre as normas que compõe o ordenamento jurídico nacional e a realidade vivida pelos presos dentro das penitenciárias, ressaltando que esta vivência contribui para a reincidência. A técnica de pesquisa adotada neste trabalho é a pesquisa bibliográfica, onde se faz uso de doutrinas, legislações pátria, de jurisprudência e de reportagens, de modo a revelar os principais pontos do tema apresentado. Por fim, o início da análise do tema deu-se pelos índices da reincidência criminal e suas causas.

Palavras-chave: Reincidência criminal. Políticas Públicas. Sistema Carcerário. Ordenamento Jurídico brasileiro.

ABSTRACT: This study will address the possibilities of penalties provided for in the Brazilian legal system and the causes of criminal recidivism, and the precariousness of the Brazilian prison system. The main objective of this work is to carry out a detailed analysis of how public policies are flawed, and with that, I contribute to the increase in recidivism. As a way to reach the objective, the dialectical methodology was used, in which it will make a comparative parallel between the norms that make up the national legal system and the reality experienced by inmates within penitentiaries, emphasizing that this experience contributes to recidivism. The research technique adopted in this work is the bibliographical research, which makes use of doctrines, national legislation, jurisprudence and reports, in order to reveal the main points of the presented theme. Finally, the beginning of the analysis of the theme was given by the rates of criminal recidivism and its causes.

Keywords: Criminal recidivism. Public policy. Prison system. Brazilian Legal System.

\footnotetext{
I Pós Graduando em Direito Penal e Processual Penal pela Faculeste (2022). Pós Graduando em Direito Penal Militar e Processo Penal Militar pela Faculesta (2023). Pós Graduando em Direito Constitucional pela Faculeste (2003). Pós Graduando em Direito do Trabalho e Processo do Trabalho - Tribunais Trabalhistas - Área Judiciária (2023). Bacharel em Direito pela Universidade Estácio de Sá (2019). Técnica em Administração pelo C.E. Erich Walter Heine (2014). E-mail: heloiza.s.lima@gmail.com
} 


\section{INTRODUÇÃO}

Com base nos diversos problemas que o Brasil vem enfrentando frequentemente, a crise no sistema carcerário pode ser apontada como um dos mais graves, e por conta disso haja uma necessidade de urgência para solucioná-lo. Esta é uma questão polêmica, tendo em visto que o tema abordado divide a sociedade entre dois grupos, um grupo cético que não acredita na ressocialização do preso e o grupo que acredita na possibilidade do preso ser ressocializado e introduzido novamente na sociedade através de políticas públicas dentro e fora dos presídios.

Ocorre que o assunto abordado vem sendo deixado de lado a anos, o que gera uma situação preocupante, uma vez que antes o tema gerava um alerta para a sociedade, hoje em dia é uma situação emergencial, uma vez que centenas de pessoas que estão no sistema prisional brasileiro encontram-se abandonadas pelo poder público e estando em situações de precariedade dentro dos presídios, este é um grande sinal do descaso absurdo dos nossos governantes com os condenados.

O Estado que por anos nunca discutiu sobre o tema, hoje vem enfrentando sérias dificuldades em sanar os problemas que foram acumulados pelo sistema carcerário brasileiro, ocorre que essas tentativas não estão tendo uma eficácia, ocorrendo então um aumento maior na crise e gerando novos problemas para o sistema penitenciário.

O cenário atual dos presídios estão provocando diversas outras dificuldade que vêm ganhando um destaque maior nas mídias, como o aumento considerado da violência, as rebeliões por conta da péssima situação no qual eles vivem, a violação dos direitos dos presos e a reincidência criminal, no qual é o objeto de estudo do presente artigo científico.

A reincidência criminal é verificada a partir do momento em que a pessoa vem a ser condenada mais de uma vez, ora, uma vez que após cumprir toda sua pessoa, ela se vê desamparada pelo Estado, e volta à prática delituosa, sendo novamente ingressada no sistema carcerário. A reincidência criminal já foi objeto de pesquisa realizada pelo Conselho Nacional de Justiça, onde ficou demonstrado a preocupação com a taxa na qual foi apontada e uma tentativa desesperada de tentar solucionar o problema que só vem aumentando de tempos em tempos. 
Quando uma pessoa ingressa novamente no sistema prisional fica evidência que o Estado foi ineficiente no seu papel para a ressocialização daquele ex-presidiário, o que nos leva a um momento de reflexão quanto a contribuição do sistema prisional para esta situação.

O assunto das infraestrutura precárias dos presídios brasileiros já foi noticiado diversas vezes pela mídia, na qual foi evidenciado a superlotação, e este fator demonstra a relação direta com o insucesso da ressocialização dos presos, causando então uma nova reincidência.

O período na qual o preso passa em reclusão, ao oposto de tornar viável o ingresso ao convívio social, faz com que os reclusos presencie uma cultura criminosa mais violenta dentro das selas, tornando assim o Estado e a sociedade seus inimigos declarados, isto faz com que eles assimilem valores adversos do bem estar da sociedades.

Com base na realidade atual, o sistema carcerário está muito distante de conseguir atingir os seus objetivos de ressocialização, uma vez que os estabelecimentos penais acabaram por se tornarem verdadeiras "escolas do crime", fazendo com que isso contribua de forma significativa com o aumento das práticas delituosas. Os próprios agentes penitenciários se deixam ser influenciados diante do cenário vivido dentro dos presídios, 1323 fazendo com que se envolvam em práticas corruptas do sistema.

Após o cumprimento da pena, o ex-detento encontra um obstáculo quase que insuperável: o preconceito da sociedade por quem já teve no sistema carcerário. Esta barreira enfrentada por quem já esteve no sistema influencia de forma expressiva para que o exdetento volte a praticar novos delitos, uma vez que o preconceito dificulta ao acesso no mercado de trabalho, sem conseguir se sustentar de forma honesta, o ex-detento não ver outra alternativa se não a volta ao mundo do crime.

O Estado tem o dever e obrigação de punir, de modo com que amedronte o criminoso caso este volte a prática de novos delitos. A punição deve mostrar à sociedade a eficácia da justiça em responder a infração cometida, e com isto, buscar novos métodos de reeducar o apenado para o retorno à sociedade. Estes métodos servem para ensinar o apenado novos ofícios para que desta forma conseguiam o seu sustento, bom convívio com sua família e com a coletividade, todavia, o Estado se torna incapaz de conseguir desenvolver esses métodos.

Diante deste fato, se faz necessário um estudos acerca dos números apresentados pelo sistema carcerário brasileiro e o que esses dados representam para a nossa sociedade, bem 
como, qual a influência que isto tem com a reincidência criminal, observando se a legislação brasileira possui medidas eficaz e se os direitos dos presos são resguardados pela legislação.

A reeducação do detento não pode apenas existir em forma de lei, se o Estado não for competente para aplicar as medidas cabíveis e com isso trazer um bom convívio do preso com a sociedade.

\section{PRINCÍPIOS NORTEADORES DO DIREITO PENAL BRASILEIRO CONTEMPORÂNEO}

Princípios constitucionais em espécie:

Princípio da legalidade (reserva legal): consiste em impedir que uma pessoa seja punida por um comportamento no qual não se configura uma prática delituosa na época em que foi praticada. $\mathrm{O}$ artigo $5^{\circ}$, inciso XXXIX da CRFB/88 aborda que uma prática não pode ser considerada crime sem a existência de uma lei, desta forma, não se pode aplicar uma pena para o ato, uma vez que não existe uma lei específica para a punição. O Código Penal brasileiro em seu artigo $\mathrm{I}^{\mathrm{o}}$ vem com o intuito de ratificar os aspectos já mencionados e amparados na Constituição Federal.

Princípio da culpabilidade (nulla poena sine culpa): este princípio verifica que ninguém pode ser qualificado como culpado senão quando tiver sua condenação por sentença penal transitada em julgado, desta forma, só pode ser condenado por sentença quando se é reconhecida a culpabilidade do agente. O princípio da culpabilidade também é tratado na Constituição Federal em seu artigo $5^{\circ}$, inciso LVII, onde aborda que ninguém poderá ser considerado culpado senão em sentença penal transitada em julgado.

Princípio da humanidade / dignidade da pessoa humana: sem dúvidas é o mais importante dos princípios constitucionais, ele vem expresso em nosso ordenamento jurídico no artigo $\mathrm{I}^{\circ}$, inciso III da $\mathrm{CRFB} / 88$, o direito penal utiliza este princípio para que não cometa excessos na hora da aplicabilidade das penas previstas em nosso ordenamento. A doutrina de André Estefam e Victor Gonçalves tende a vislumbrar dois aspectos deste princípio no direito penal, são eles: "a proibição de incriminação de condutas socialmente inofensivas (afinal, direito é que está a serviço da humanidade, e não o contrário); e a vedação de tratamento degradante, cruel ou de caráter vexatório”. (André Estefam e Victor Gonçalves, 2017, p. 103.)

Canotilho pondera que: 


\begin{abstract}
"perante as experiências históricas de aniquilação do ser humano (inquisição, escravatura, nazismo, stalinismo, polpotismo, genocídios étnicos), a dignidade da pessoa humana como base da República significa, sem transcendências ou metafísicas, o reconhecimento do homo noumenon, ou seja, do indivíduo como limite e fundamento do domínio político da República. Neste sentido, a República é uma organização política que serve o homem, não é o homem que serve os aparelhos políticos-organizatórios”. (Alexandre Moraes, 2000, p. 225.)
\end{abstract}

Princípios derivados ou decorrentes:

Princípio da retroatividade benéfica da lei penal: este princípio nada mais é que uma exceção em nosso sistema jurídico, uma vez que, a regra geral é o da irretroatividade da lei penal. O princípio da retroatividade vem com o intuito de beneficiar o réu, uma vez que os efeitos e benefícios favoráveis de uma norma penal retroage ilimitadamente e indiscriminadamente para todos os ocorridos anteriores à sua entrada em vigência, conforme aborda o artigo $2^{\circ}$, parágrafo único do Código Penal. Vale ressaltar que se tratando de normas de caráter estritamente processual, não poderemos fazer o uso da aplicabilidade do princípio da retroatividade benéfica da lei penal.

Sobre as normas de caráter mistos ou híbridos, as que tiverem aspectos processuais não poderão fazer uso do mencionado princípio, salvo se benéficas, respeitando sempre a coisa julgada.

André Estefam e Victor Gonçalves exemplificam que:

\begin{abstract}
"uma lei que passe a estabelecer uma condição de procedibilidade até então não exigida para determinado crime (como a exigência de representação no crime de estupro cometido com violência real praticado contra vítimas maiores de 18 anos e não vulneráveis, o qual passou a depender de representação do ofendido com o advento da lei n. 12.015/2009)". (André Estefam e Victor Gonçalves, 2017, p. 126.)
\end{abstract}

Princípio da insignificância ou da bagatela: para entender melhor este princípio basta a aplicação de um simples caso concreto onde um indivíduo entra em um estabelecimento de venda comercial de materiais escolares e subtrai uma folha de papel carbono, realiza uma ação formalmente típica, pois o ato praticados está elencado no artigo 155, CAPUT do Código Penal, mas materialmente atípica, pois o dano material sofrido pelo estabelecimento é insignificante, o que torna a aplicação de uma pena injustificável. Segundo o entendimento do Supremo Tribunal de Justiça "O princípio da insignificância se refere à hipótese de ofensa mínima a bem jurídico que não deve ser confundido com a proporção de dano em relação ao patrimônio do sujeito passivo”. (STJ - RHC 6319/PR - 5 $5^{\text {a }}$ Turma, Rel. Min. Fleix Fisher, DJU 23/6/1997, p. 29.166.) 
Princípio da bagatela imprópria: diferente do princípio da insignificância, onde é afastado a tipicidade material, o princípio da bagatela imprópria, uma vez reconhecida, exclui a culpabilidade no ato praticado.

André Estefam e Victor Gonçalves assevera que:

\begin{abstract}
“Aplica-se o princípio nas seguintes situações: ínfimo desvalor da culpabilidade, ausência de antecedentes criminais, reparação dos danos, reconhecimento da culpa ou a colaboração com a justiça, os quais, apreciados globalmente e verificados no caso concreto, podem tornar a imposição da pena desnecessária". (André Estefam e Victor Gonçalves, 2017, p. 133.)
\end{abstract}

Princípio do fato: o Estado tem o direito de punir, porém sem sancionar condutas puramente subjetivas, ou seja, não se pode punir atos que são incapazes de ferir bens jurídicos.

André Estefam e Victor Gonçalves ressaltam que: “(...) Ninguém pode ser punido pelo simples pensar (cogitationis poenam nemo patitur)”. (André Estefam e Victor Gonçalves, 2017, p. 136.)

Princípio da alteridade ou transcendentalidade: de acordo com este princípio o direito penal tão somente poderá punir atos que causem lesões a terceiros, ou seja, se o ato praticado causar danos apenas para o próprio agente, será classificado como um ato penal irrelevante.

Estefam e Gonçalves exemplificam que:

"O consumo de drogas, realizado individualmente e em ambiente privado, também não constitui crime, pois, neste cenário, o comportamento não põe em risco o bem jurídico protegido (a saúde coletiva), motivo por que o ato não se reveste de tipicidade penal”. (André Estefam e Victor Gonçalves, 2017, p. 136.)

Princípio da exclusividade proteção de bens jurídicos: ele é derivado do princípio da dignidade da pessoa, pode-se dizer que o direito penal não pode tutelar valores meramente morais, religiosos, ideológicos ou éticos, mas tão somente atos atentatórios a bens jurídicos.

De acordo com Claus Roxin, "a proteção de normas morais, religiosas ou ideológicas, cuja violação não tenha repercussões sociais, não pertence, em absoluto, aos limites do Estado Democrático de Direito, o qual também deve proteger concepções discrepantes entre as minorias”. (Claus Roxin, 1997 , p. 63.)

Um ótimo exemplo é o artigo 276 do antigo Código Criminal do Império, onde era qualificado como contravenção penal a celebração em templos ou publicamente de cultos relativos à religião diversa do Estado.

Princípio da ofensividade ou lesividade: não existe crime sem lesão efetiva ou 
ameaça ao bem jurídico tutelado (nullum crimen sine iniuria), ou seja, para ser configurado crime o ato praticado deve ser resultado de uma lesão ou perigo de lesão.

Exemplificando melhor: O atual Código de Trânsito de 1997, considera crime a embriaguez ao volante, conforme artigo 306. Na redação original trata-se de crime de perigo concreto, o qual, após a edição da "Lei Seca", tornou-se de perigo abstrato. Cabe ressaltar que boa parte da doutrina e jurisprudência admitem os crimes de perigo abstrato.

Com base no entendimento pacificado do Supremo Tribunal Federal, o crime do artigo 306 do CTB é de perigo abstrato e é dispensado a demonstração de potencialidade lesiva na conduta, configurando desta forma pela simples condução ao veículo automotor.

Princípio da intervenção mínima (subsidiariedade e fragmentariedade): o direito penal deverá ser utilizado em último caso, uma vez que, suas penalidades atingem de forma mais intensa a liberdade do indivíduo. Desta forma, cabe ao Estado sempre que possível recorrer de meios menos lesivos para trazer de volta o convívio e a paz social.

Estefam e Gonçalves exemplificam que: "Se alguém dirige seu automóvel e, ao mesmo tempo, fala ao telefone celular, a imposição de uma multa de trânsito constitui punição suficiente e proporcional ao ato)". (Estefam e Gonçalves, 2017, p. I40.)

Ou seja, neste caso concreto não se fez necessário a aplicação das penas prevista no código penal, bastou a aplicação de multa para a solução do caso.

Princípio da adequação social: por este princípio entende-se que não se pode reputar criminosamente uma conduta tolerada pela sociedade, ainda que esteja enquadrada como uma conduta de descrição típica.

Este princípio foi desenvolvido pelo autor Hans Welzel, segundo ele: "são aquelas atividades nas quais a vida em comunidade se desenvolve segundo a ordem historicamente estabelecida" (Hans Welzel, 2007 , p. 50-5I.)

Este princípio serve para que o legislador consiga verificar quais os atos humanos são merecedores de punição criminal, sempre tendo em mente os atos socialmente adequados.

Princípio do ne bis in idem: este princípio vem com o dever de vedar que um indivíduo seja julgado duas vezes pelo mesmo fato delituoso.

Para o Supremo Tribunal Federal, mesmo não se tratando de um princípio explícito em nossa Constituição Federal, a incorporação ao ordenamento jurídico penal 
complementa os direitos e as garantias individuais previstos em nosso ordenamento, desta forma, o direito à liberdade, consagrado expressamente em nossa Constituição, quando amparado em coisa julgada material, deve prevalecer sobre o dever estatal de acusar.

Princípio da humanidade: este princípio versa sobre a dispensa do tratamento humanizado aos sujeitos ativos de infrações penais, obviamente que, são vedadas as penais mencionadas no artigo $5^{\circ}$, inciso III da CF e as penas do artigo $5^{\circ}$, inciso XLVII da CF. Este princípio é derivado do princípio da dignidade da pessoa humana.

Conforme Luiz Luisi, "postulado reitor do cumprimento da pena privativa de liberdade”. Seguindo a linha de raciocínio do autor vale ressaltar sua fala sobre: "o indeclinável respeito ao princípio da humanidade não deve obscurecer a natureza aflitiva da sanção penal”. (Luiz Luisi, I99I, p. 46.)

Princípio da proporcionalidade (proibição do excesso e da proteção deficiente): este princípio contém uma formulação teórica mais apurada, e nela temos três dimensões, quais sejam: juízo de adequação, de necessidade e de proporcionalidade em sentido estrito, temos que ficar atentos para não confundir com o princípio da razoabilidade.

A proibição do excesso e da proteção deficiente é meramente um auxiliador para que se seja determinada a medida.

O Supremo Tribunal Federal, já aplicou o princípio em temas ligados ao direito penal, foi

o caso da ação direta de inconstitucionalidade ajuizada em face do estatuto do desarmamento.

\section{PENAS PREVISTAS NO CÓDIGO PENAL E SUAS FUNÇÕES}

As penas previstas em nosso ordenamento jurídico são ferramentas que o estado utiliza para punir aqueles que violam nosso sistema. Quando o agente pratica fato típico, ilícito e culpável, abre margem para que o Estado faça uso do seu jus puniendi.

Cabe ressaltar que o Direito Penal é abraçado pelo princípio da ultima ratio, que nada mais é que o princípio da intervenção mínima, onde o Estado deve se utilizar da lei penal como último recurso, quando houver extrema necessidade para a solução do conflito.

Contudo, vivemos em um Estado Constitucional de Direito, onde deve ser respeitado os princípios norteadores na hora da aplicabilidade das penas, uma vez que nossa Constituição Federal bane algumas formas de punições que antes eram aceitas, exemplo pena de morte; 
banimento, entre outros. Nosso ordenamento tão somente permite as penas privativas de liberdade; restritivas de direito e de multa.

O Código Penal recepcionou as penas privativas de liberdade; restritivas de direito e de multa em seu artigo 32. As penas privativas de liberdade para os crimes ou delitos são as de reclusão e detenção (reclusão deve ser cumprida em regime fechado, semiaberto ou aberto); (detenção deve ser cumprida em regime semiaberto, ou aberto).

Ocorrendo concurso material (artigo 69 do Código Penal brasileiro), serão aplicadas cumulativamente as penas de reclusão e de detenção, sendo observado a aplicabilidade da pena mais gravosa em primeiro momento.

Sobre as medidas de segurança, se o fato aplicado pelo agente imputável for passível de punição de detenção, caberá ao juiz submeter o réu ao tratamento ambulatório.

Nos casos de prisão preventiva, estando presente todos os requisitos do artigo 32 do Código Penal brasileiro, poderá ser decretado nos casos de crimes dolosos a reclusão, todavia, nos casos de detenção, somente será admitido a prisão preventiva quando o réu for considerado vadio, e quando se tem dúvida quanto a sua identidade.

De acordo com o artigo 332 do Código de Processo Penal, o agente policial poderá conceder fiança nas hipóteses das infrações punidas com detenção. Aos crimes dolosos contra a vida será passível de punição de reclusão, haja visto que são crimes de caráter inafiançável.

Segundo a Lei de Contravenções Penais, a pena privativa de liberdade possui caráter de prisão simples. $O$ agente condenado a prisão simples deverá cumprir sua pena separado daqueles que foram condenados à reclusão ou detenção.

As penas restritivas de direitos estão amparadas no artigo 43 do Código Penal brasileiro, onde estão taxadas as restrições permitidas, tais como: prestação pecuniária; perda de bens e valores; prestação de serviços à comunidade ou entidades; interdição temporária de direitos; limitação de fim de semana.

Prestação pecuniária significa o pagamento em dinheiro à vítima do fato, seus dependentes ou às entidades públicas/privadas com destinação social, cabe ao juiz fixar a aplicabilidade da pena entre i e 360 salários mínimos vigentes no território nacional.

Perda de bens e valores é a pena que impõe ao condenado perda em favor do fundo penitenciário nacional do montante do prejuízo causado ou a vantagem conseguida com a prática do fato delituoso. 
Prestação de serviços à comunidade ou entidades públicas, trata-se de atribuição ao condenado de tarefas gratuitas em escolas, hospitais, clubes, entidades assistenciais, onde serão calculadas à razão de uma hora de tarefa por dia de condenação, sem que ocorra o prejuízo da jornada de trabalho normal.

Interdição temporária de direitos, esta modalidade se subdivide em outras quatro espécies, quais sejam: proibição do exercício de cargo, função ou atividade pública ou mandato eletivo; proibição do exercício de profissão, atividade ou ofício que dependam de habilidade especial; suspensão da autorização ou habilitação da carteira de motorista; proibição para frequentar determinados lugares.

Limitação de fim de semana, consiste na obrigação do condenado de permanecer, aos sábados e domingos, por cinco horas diárias, em casas de albergues ou de outro estabelecimento considerado adequado pelo poder judiciário, durante esta permanência, poderá ser ministrado ao condenado cursos, palestras ou atividades educativas.

Segundo Damásio de Jesus, "as sanções e medidas que não envolvam a perda de liberdade". (Damásio de Jesus, 200o, p. 28.)

As penas alternativas segundo Fernando Capez "são as opções oferecidas pela lei penal a fim de que evite a pena privativa de liberdade" (Fernando Capez, 2011 , p. 344.)

As penas restritivas de direitos tem uma essência de cunho social e econômico, uma vez que tem como objetivo evitar o encarceramento, a fim de conscientizar o agente de suas responsabilidades perante a sociedade, desta forma, possibilitando uma reabilitação mais saudável para o agente.

As penas restritivas de direito são classificadas como genéricas e específicas. As específicas são aquelas que se aplicam apenas nos casos em que o crime é determinado, ou seja, exige uma relação entre a espécie de crime e a espécie de pena, as genéricas são as demais, aquelas que substituem as penas de qualquer crime.

A pena de multa tem caráter pecuniária, seus cálculos são baseados no sistemas de dias-multa, que poderá variar entre ıo (dez) dias, chegando ao máximo legal permitido de 360 (trezentos e sessenta) dias. Vale ressaltar que o valor correspondente a cada dia multa será de I/30 do valor do salário mínimo vigente no território nacional à época dos fatos, podendo chegar até 5 (cinco) vezes este valor.

Conforme o artigo 6o, parágrafo Io do Código Penal brasileiro, cabe ao juiz aplicar a 
pena de multa sempre se atentando ao sistema econômico do réu, com isto, podendo até triplicar o valor correspondente.

A pena de multa poderá ser prevista na legislação de forma isolada, como nos casos das contravenções penais; poderá ser discriminada de modo alternativo, ou seja, será imposto pena privativa de liberdade ou multa; poderá ser cumulativa, aplicar a pena privativa de liberdade e multa e por fim, poderá ser vicariante ou substitutiva, neste caso, cabe ao juiz substituir a pena privativa de liberdade por pena de multa, é um ato para beneficiar o agente.

Cabe ressaltar que, conforme a Lei $9.268 / 96$ é proibido a conversão de multa em detenção, uma vez que o não pagamento da multa se torna mais grave do que o próprio crime, nosso ordenamento não mais admite a prisão por dívida, desta forma, o não pagamento da multa será considerado dívida de valor, aplicando então a legislação referente à dívida ativa da Fazenda Pública.

As penas previstas no Código Penal brasileiro tem como função conter a criminalidade e causar um possível amedrontamento aos possíveis infratores, desta forma, trazendo uma segurança jurídica maior ao poder judiciário e a sociedade.

Existem três teorias que visam explicar as finalidades das penas previstas em nosso

ordenamento jurídico, são elas: teoria absoluta ou da retribuição onde a finalidade da pena é de punir o infrator pela mal causado à sociedade;

Teoria relativa ou da prevenção, esta tem por finalidade a intimidação, para que assim consiga evitar possíveis delitos; E por último, teoria mista ou conciliatória, neste caso a pena terá uma dupla finalidade, ou seja, ela irá punir e prevenir.

A aplicação da pena ao condenado possui quatro principais fundamentos, neste caso serão observadas as consequências práticas da condenação. Estes fundamentos são: preventivo, onde se busca através da norma penal incriminadora intimidar a sociedade sobre a prática de atos ilícitos. $\mathrm{O}$ ato preventivo ainda é passível de uma subdivisão de caráter geral e especial;

Retributivo, neste caso a pena será uma forma de castigo ao transgressor de forma proporcional ao mal que foi causado, sempre dentro dos limites constitucionais, exemplificando, o agente que comete homicídio doloso não poderá ser castigado com a pena de morte, mas sim, através da pena privativa de direito.

Reparatório, neste caso ele tem caráter de compensar a vítima e/ou seus parentes 
pelas consequências advindas do ato delituoso. A obrigação de reparar o dano tem efeito secundário.

E por último, readaptação, onde se busca a aplicabilidade das penas, junto com a reeducação e reabilitação do criminoso ao convívio social, desta forma, o preso deverá receber estudo, orientação, possibilidade de trabalho, lazer, aprendizado de novas formas laborativas, dentre outras coisas.

\section{ÍNDICES DE REINCIDÊNCIA CRIMINAL NO BRASIL}

O índice atual de reincidência no Brasil tem crescido de forma alarmante, este fato já foi sujeito de pesquisa por grandes instituições. Em 2015 foi publicado um relatório da pesquisa que teve sua denominação de "Reincidência Criminal no Brasil", realizado pelo Instituto de Pesquisa Econômica Aplicada (Ipea) por solicitação do Conselho Nacional de Justiça (CNJ).

$O$ resultado obtido nesta pesquisa foi que, em cada quatro ex presos um vem a ser condenado novamente dentro do prazo de 5 anos, atingindo então um índice de $24,4 \%$ da população carcerária brasileira.

Cabe ressaltar que segundo o Ipea, a reincidência criminal não é alvo de pesquisa constante, o que faz com que o índice possa variar muito de ano para ano e abre margem para que a mídia faça especulações um tanto quanto absurdas.

Frequentemente ficamos diante de informações que nos são passadas através da mídia em que a taxa de reincidência no Brasil é de 70\%. E de onde a mídia tira estas informações? Bom, em 2008 foi divulgado um relatório da CPI do sistema carcerário, e lá a taxa de reincidência dos detentos em relação ao crime chegou de $70 \%$ a 80\%, conforme a Unidade da Federação.

Porém, a CPI não produziu uma pesquisa que pudesse avaliar a veracidade destes números que foram apresentados, boa parte da pesquisa se baseou tão somente nos dados que foram informados pelos presídios.

A maior e talvez principal pesquisa realizada sobre este tema no Brasil foi do doutrinador Adorno e Bordini (1989), no qual utilizou todos os sentenciados libertados da penitenciária do Estado de São Paulo entre os anos de 1974 e 1976 . Ele se utilizou do conceito de reincidente penitenciário, que nada mais é do que o sujeito que, tendo cumprido sua pena, 
volte à prática criminosa e seja novamente habitante dos presídios. Em sua pesquisa, o doutrinador chegou a taxa de 46,03\%, um número um tanto quanto distante daquele que foi divulgado pela CPI.

Lemgruber (1999), produziu um estudo semelhante no Desipe no ano de 1988, o estudo foi baseado em entrevistas na qual teve a taxa de 30,7\% de reincidência criminal, sendo que $31,3 \%$ da reincidência eram cometidas por homens e $26 \%$ por mulheres.

Adorno e Bordini produziram outro estudo, todavia, este teve como base o conceito jurídico de reincidência criminal definida no código penal de $1940 \mathrm{com}$ as alterações da lei 6.416/77 e pela lei das Contravenções penais de 4I. Esta pesquisa levou em consideração apenas os detentos já condenados pelo sistema de justiça criminal paulistana, neste caso, o índice de reincidência foi de apenas $29,34 \%$.

Em 1994, o Censo Penitenciário Nacional chegou a conclusão que 34,4\% dos apenados no Brasil eram reincidentes. Porém, em 1997, o Ministério da Justiça substituiu o termo reincidência penal por reincidência penitenciária, para este termo o reincidente é aquele que cumpriu pena, foi solto e voltou a ser preso para o cumprimento de uma nova pena.

Kahn (200I), também realizou uma pesquisa baseando-se tão somente no Estado de São Paulo, neste caso a taxa foi de 50\% no ano de $1994 ; 45,2 \%$ em 1995 e $47 \%$ no ano seguinte. Os índices demonstraram que a taxa de reincidência varia bruscamente de ano para ano, sendo necessário um estudo anual para controle concreto da reincidência.

O Ministério da Justiça, por meio do Depen, concluiu que a reincidência criminal é fato difícil de ser apurado precisamente, haja visto que, existem diversos fatores que colaboram para uma variante constante. No relatório apresentado pelo Depen no ano de 1998 a taxa era de 70\%, a meta apresentada era em redução na metade para o ano de 2003, esta pesquisa pode ser a origem $d a$ porcentagem que foi apresentada amplamente para a população.

Se faz necessário constar que a taxa de reincidência criminal varia muito em função do conceito que é utilizado para a elaboração das pesquisas, todavia, notamos que os índices são sempre altos (constando que as menos estimativas ficam em torno de $30 \%$ ).

Esses índices têm levado a sociedade e o poder público a refletirem mais sobre as atuais políticas de execução penal, fazendo com que haja a necessidade de modificação de algumas dessas políticas, pois, o atual sistema apenas privilegia o encarceramento maciço. 


\section{CAUSAS DA REINCIDÊNCIA CRIMINAL NO BRASIL}

Se faz necessário traçar um perfil para os reincidentes, que em sua maioria são homens jovens, com baixo nível de escolaridade e de etnia negra, a reincidência em boa parte do tempo é cometida por crimes contra o patrimônio (como por exemplo roubo e furto) e também por crimes relacionados a drogas (como por exemplo porte e consumo).

Diante destes traços surge a necessidade de entender melhor os motivos que levam a reincidência a alcançar índices relativamente elevados.

Acontece que os índices são uma consequência de fatores, que juntos corroboram para crescimento da reincidência. Esses fatores vão desde a falha estatal em não agir com medidas que possam transformar a vida do apenado durante a execução da pena, até a ausência de novas oportunidades de emprego para aqueles que já cumpriram a pena.

A ausência de oportunidades ao acesso à educação e consequentemente, ausência de formação profissional, colaboram expressivamente para a dificuldade das pessoas que passaram pelo sistema criminal em conseguir emprego, e desta forma excluindo-os socialmente, gerando assim, um preconceito criado pelo estigma de ser um ex-presidiário.

Este preconceito surge por achar que pessoas que passam pelo sistema carcerário brasileiro não podem se desprender da violência cometida, e muito menos são merecedoras de um voto de confiança.

A prática de uso das drogas também contribui de forma abundante para a prática de novos delitos, uma vez que o usuário que não recebe tratamento adequado tende a procurar por meios que lhe são acessíveis, ilegalmente, para satisfazer seu desejo.

Desta forma, comentem diversos tipos de crimes para que então consigam se auto satisfazer, e esses crimes na grande maioria das vezes são cometidos de forma violência.

Cabe salientar que, a própria experiência caótica vivida dentro dos presídios, acaba se tornando um meio para que a ressocialização se torne algo impossível, uma vez que o detento não possui tratamento adequado dentro dos presídios. Fazendo com que saiam de lá mais violentos do que entram, pois são tratados desumanamente.

A exclusão social, as dificuldades no cumprimento das penas dentro e fora do sistema penal, a falta de oportunidade para os ex-detentos, o desemprego, o vício, o preconceito e a facilidade em ingressar na vida criminal, são alguns dos fatores que colabora para que o 
indivíduo pratique novas infrações penais, e com isso retornem para as prisões.

\section{CONTRIBUIÇÃO DAS PENAS PARA EVITAR A REINCIDÊNCIA CRIMINAL}

A Lei de Execução Penal tem por objetivo efetivar as decisões penais e proporcionar condições harmônicas para a integração social do condenado e do internado para o convívio social sem dificuldades destes, conforme dispõe o artigo Io da LEP.

A LEP prevê diversas garantias que deveriam ser empregadas para proporcionar a recuperação do preso e como consequência a sua reintegração na sociedade. $O$ artigo io da LEP diz que é dever do Estado dar assistência ao preso e com isso prevenir o crime e orientar o detento ao retorno à sociedade.

Para o juiz auxiliar Luís Geraldo Sant'Ana Lanfredi, há uma necessidade de observar os diversos motivos que levam à reincidência, e desta forma criando políticas públicas que possam ser aplicadas a cada caso.

Muitos dos programas previstos na LEP para ressocialização dos presos já funcionam nos estados brasileiros, ainda que insuficientes. Entre estas medidas, podemos citar a oferta de programas de estudo e leitura, como possibilidade de diminuição da pena, e ainda possibilidade do preso em aprender um novo ofício, para que desta forma consiga entrar no mercado de trabalho.

Esta medida tem como o intuito de formação para que o preso esteja melhor preparado para o mercado de trabalho e consiga voltar ao âmbito da sociedade com menos dificuldade, fazendo com que não sofra preconceito.

Outra modalidade é o trabalho laboral, que consiste em que o preso trabalhe fora do presídio e com isso diminua sua pena, ainda, ajuda no aprendizado de novos ofícios, melhorando então seu ingresso na sociedade.

Segundo Lanfredi, "é imprescindível lidar melhor com todas as ações e opções desde o primeiro momento em que uma pessoa tem contato com o sistema de Justiça criminal, fomentando medidas que desestimulem o crime e resultem em investimento social”. (Luís Geraldo Sant'Ana Lanfredi, 2015)

Os altos índices de criminalidade e, por consequência, da reincidência decorrem da sensação de impunidade, que nada mais é do que resultado da incapacidade do Estado em intervir de forma transformadora na vida de quem pratique infrações penais. 
O grande problema no sistema penal decorre da ineficácia do Estado em aplicar o que dispõe a LEP, do que adiante está disposto na lei as formas de ressocialização do condenado, se para o Estado estas medidas não servem para ser aplicadas.

Ora, do que adianta a LEP ter medidas eficazes para a diminuição da reincidência criminal dando formas do detento para voltar ao ingresso na sociedade, se o Estado é incapaz de aplicá-las nos casos concretos, se faz necessário uma intervenção maior do Estado frente a reincidência.

\section{CONCLUSÃO}

Diante de todo o exposto neste artigo científico, é evidente a grande importância que o período de reclusão tem na vida de um detento. Se o Estado continuar sendo falho na forma de coibir a reincidência criminal, de nada irá adiantar as medidas previstas em lei. $\mathrm{O}$ Estado deve apostar na educação e assistência social, para que com isso o preso consiga ingressar na sociedade sem ser discriminado, dando a ele novas oportunidades, tanto no convívio com a sociedade, quanto no mercado de trabalho.

O ordenamento jurídico brasileiro prevê diversas formas de proteção e auxílio ao detento, assegurando assim, seus direitos fundamentais, todavia, sabemos bem que a realidade é outra, uma vez que a dignidade da pessoa humana é o direito fundamental mais violado.

O Estado ainda tem uma ineficiência muito grande quanto a aplicabilidade com êxito do que vem previsto em lei, não são fornecidas condições necessárias para a realização dos programas de reeducação do detento, para que assim o preso consiga enxergar a vida com outros olhos.

Única coisa que conseguimos nota com muita clareza é a precariedade dos estabelecimentos prisional por todo o Brasil, os apenados vivem em um regime totalmente desumano, celas pequenas e totalmente lotadas sem nenhum tipo de condição básico como higiene, alimentações inadequadas, e sem nenhum tipo de acesso a possibilidade de oportunidades de trabalho ou a educação.

Para muitas pessoas o preso nunca possuiu um trabalho de cunho honesto antes da vida do crime, porém como apontou a pesquisa realizada pelo IPEA e divulgada pelo CNJ, a 
maior parte da população carcerária brasileira possuíam trabalhos honesto, porém a forte crise em nosso país fez com essas pessoas entrassem para a prática do crime a fim de se sustentarem.

Boa parte dos presos entram no sistema carcerário por conta da prática de crimes taxados como leves, entretanto a experiência que eles têm dentro do encarceramento os levam a praticar crimes mais graves. $O$ ambiente no qual eles são submetidos gera um sentimento de revolta por conta do descaso por parte do Estado e exclusão social.

Os números demonstrados na pesquisa apontam para uma crise carcerária que vem ocorrendo há anos, e o Estado não toma nenhum tipo de atitude para tentar amenizar este fato. Para o poder público a reeducação fica em última instância, a prioridade para eles e a construção de novos presídios, seria o mesmo que o ditado popular "tapar o sol com a peneira".

A sociedade também tem um papel fundamental, porém eles não conseguem enxergar este fato, para eles as políticas públicas servem apenas para desperdiçar o dinheiro público, uma grande parte da sociedade considera justa o nível de desumanidade que os detentos vivem dentro das celas.

Porém, a sociedade e o poder público não conseguem se conscientizar sobre a necessidade de políticas públicas para a recuperação deste preso, sem esta recuperação acabamos por nos tornar novas vítimas de atos criminosos.

A reincidência criminal é um retrato claro sobre a experiência ruim que os presos adquirem dentro dos presídios por conta de todo o descaso que eles sofrem, isto é uma consequência da ineficácia do Estado perante as medidas de ressocialização.

Para acabar de fato com a reincidência criminal no país, se faz necessário uma intervenção imediata do Estado no ordenamento jurídico penal, uma vez que o código penal brasileiro não acompanha de fato as mudanças em sociedade, e ora que se tem a LEP para instruir as execuções penais e o Estado se omitindo a aplicá-los.

\section{REFERÊNCIAS BIBLIOGRÁFICAS}

Livros

ESTefAM, André; GONCALVES, Victor Eduardo Rios. Direito Penal Parte Geral. 6a ed. 
Editora Saraiva. 2017.

CAPEZ, Fernando. Curso de Direito Penal Parte Geral. 13 $3^{\underline{a}}$ ed. Editora Saraiva. 20Ir. GRECO, Rogério. Curso de Direito Penal Parte Geral. 13 $3^{\underline{a}}$ ed. Editora Impetus. 20II. MORAES, Alexandre. Direito Constitucional. $7^{\text {a }}$ ed. Editora Atlas S.A. 2000.

FAVORETTO, Affonso Celso. Princípios Constitucionais Penais. I르 ed. Editora Revista dos Tribunais. 2012.

JESUS, Damásio E. Penas Alternativas. $2^{\mathrm{a}}$ ed. Editora Saraiva. 2000.

ROXIN, Claus. Derecho Penal Parte General Tomo I Fundamentos La Estructura de La Teoría Del Delito. 2 ${ }^{\underline{a}}$ ed. Editora Civitas. 1997.

WELSEL, Hans. Estudios de Derecho Penal. 6a ed. Editora Editorial B de f. 2007.

Publicações Periódicas Artigo

de periódico

ADORNO, Sérgio; BORDINI, Eliana B. T. Reincidência e reincidentes penitenciários em São Paulo (1974 - 1985). Revista Brasileira de Ciências Sociais, São Paulo: Anpocs, v. 3, n. 9, pg. 70-94, fev. 1989 .

ADORNO, Sérgio; BORDINI, Eliana B. T. A prisão sob a ótica de seus protagonistas: itinerário de uma pesquisa. Revista de Sociologia da USP, Tempo Social, São Paulo, v. 3, n. I-2, pg. 7-40, I99I.

LEMGRUBER, Julita. Reincidência e reincidentes penitenciários no sistema penal do Estado do Rio de Janeiro. Revista da Escola de Serviço Penitenciário do Rio Grande do Sul, Porto Alegre, anor, no 2,pg. 45-76, jan/fev/mar. 1989.

\section{Artigo}

KAHN, Tulio. Além das Grades: radiografia e alternativas ao sistema prisional.

Editora Conjuntura. 2014.

BRASIL. Congresso Nacional. Câmara dos Deputados. Comissão Parlamentar de Inquérito do Sistema Carcerário. Relatório Final. Jul. 20o8b.

BRASIL. Ministério da Justiça, Departamento Penitenciário Nacional (Depen).

Sistema Nacional de Informações Penitenciárias - InfoPen, 200 . 
Coordenador do Departamento de Monitoramento e Fiscalização do sistema carcerário e do sistema de execução de medidas socioeducativas (DMF) do Conselho Nacional de Justiça, o juiz auxiliar Luís Geraldo Sant'Ana Lanfredi.

Ipea. Reincidência Criminal no Brasil. Relatório de Pesquisa. 2015.

Documento Jurídico

Constituição Federal

BRASIL. Constituição (1988). Constituição da República Federativa do Brasil.

Brasília, DF: Congresso Nacional, 1988.

\section{Códigos}

BRASIL. Código Criminal (I830). Código Criminal do Império do Brazil. Rio de Janeiro, RJ: Assembleia Geral, ı8zo.

BRASIL. Código Penal (1940). Código Penal Brasileiro. Rio de Janeiro, RJ, 1940.

BRASIL. Código de Trânsito (1997). Código de Trânsito Brasileiro. Brasília, DF,

1997.

\section{Legislação}

Lei de Execução Penal - Lei no 7.210, de II de julho de 1984. Brasília-DF.

Lei no 6.416, de 24 de maio de 1977. Brasília-DF.

Lei de Crimes Sexuais - Lei no ${ }_{12.015}$, de 7 de agosto de 2009, Brasília-DF. Lei Seca -

Lei no 11.705 , de 19 de junho de 2008, Brasília-DF.

Lei no 9.268, de or de abril de 1996, Brasília-DF.

Habeas Corpus

STJ - RHC: 6319 PR 1997/oor6349-o, Relator: Ministro FELIX FISCHER, Data de

Julgamento: 20/o5/1997, T5 - QUINTA TURMA, Data de Publicação: DJ 23/o6/1997 p. 29166.

STF - HC: 86606 MS, Relator: CÁRMEN LÚCIA, Data de Julgamento: 22/05/2007, Primeira 
Turma, Data de Publicação: DJe-072 DIVULG o2-08-2007 PUBLIC 03-o8-2007 DJ 03-08-2007 PPooo86 EMENT VOL-02283-04 PP-oo638. STJ - HC: 231.566 RJ, Rel. Ministro OG FERNANDES, SEXTA TURMA, DJe de 28/o6/2013.

Ação direta de inconstitucionalidade STF - $\quad$ ADI: 3 IIn DF, Relator: Min. RICARDO LEWANDOWSKI, Data de Julgamento: 02/05/2007, Tribunal Pleno, Data de Publicação: DJe-13I DIVULG 25-10-2007 PUBLIC 26-10-2007 DJ 26-10-2007 PP-00028 EMENT VOL-02295-03 PP-00386 RTJ VOL00206-02 PP-00538.

Em meio eletrônico

PACI, Maria Fernanda. Princípios constitucionais informadores da pena e a sua função ressocializadora. In: Âmbito Jurídico, Rio Grande, XVII, n. I3I, dez 2014. Disponível em: <http://www.ambitojuridico.com.br/site/index.phpn_link=revista_artigos_leitura\&artigo_id= I 4395\&revista_caderno=9>. Acesso em maio 2019.

CARVALHO, Ana Carolina Oliveira. A reincidência criminal em decorrência da precariedade do Sistema Carcerário brasileiro. Conteúdo Jurídico, Brasília-DF: 20 nov. 2017.Disponível em: $\langle$ http://www.conteudojuridico.com.br/?artigos \&ver=2.590035\&seo=I $>$. Acesso em: io maio 2019.

SOUZA, Isabela. 4 Pontos para entender a reincidência criminal. Politize, Santa Catarina: 28 abril 2017. Disponível em: 〈https://www.politize.com.br/reincidencia-criminal- entenda/〉. Acesso em: Io maio 2019. 